\title{
Decoding electrocardiographic predictors of left ventricular mechanical remodeling in patients with left bundle branch block
}

\author{
Oana Andrei', Florin Barbu', Liliana Anghel', Carmen Ginghina ${ }^{1,2}$, Radu Ciudin ${ }^{1,2}$
}

\begin{abstract}
Introduction - Left bundle branch block (LBBB) occurrence is uncommon in the general population ( I-3\%), but is more prevalent among patients with congestive heart failure $(\sim 30 \%)$, and portends worse prognosis ${ }^{1-3}$. The impact of LBBB on left ventricular (LV) systolic function can range from minimal to dramatic reduction of ejection fraction. The delay in electrical activation subsequently triggers dyssynchronous contraction of the LV opposing walls, leading to ventricular remodeling and elevated LV filling pressures ${ }^{6,7}$. This is turn results in electrical and mechanical left atrium (LA) remodeling. The left ventricular activation time (LVAT) and P-wave terminal force in lead VI (PTFVI) have been correlated with cardiac resynchronization response. However, the relationship between these electrocardiographic markers and LV mechanical remodeling has not been evaluated. Aims - The aim of this study is to investigate the relationship between LVAT and PTFVI recorded on ECG and the LV mechanical remodeling evaluated by the left ventricular end-diastolic diameter (LVEDd) in patients with LBBB. Methods - We have conducted a retrospective, observational study on 155 consecutive patients diagnosed with LBBB admitted in our clinic between January 2017 and December 2019 with NYHA class I-IV, regardless of the left ventricle ejection fraction (LVEF). Biventricular electrical activation in LBBB was performed by measuring the right and left ventricular activation times (RVAT, LVAT) and electrical activation of the LA was analyzed by measuring P-wave terminal force in lead VI (PTFVI). Results - In our cohort, LVEDd is statistically significantly correlated with LVAT and PTFVI, with a higher Pearson correlation coefficient for LVAT compared to PTFVI. In multivariate analysis LVAT and PTFVI are independent predictors of LVEDd. Conclusion - This study suggests that LV mechanical remodeling in patients with LBBB can be predicted by the delayed electrical activation of the LV and the magnitude of $\mathrm{P}$-wave negative terminal forces in VI. Keywords: left bundle branch block, electrocardiography, P - wave terminal forces in VI, left ventricular remodeling.
\end{abstract}

Rezumat: Introducere - Blocul complet de ramură stângă (BRS) este rar în populația generală ( 5\%), dar relativ frecvent în rândul pacienților cu insuficiență cardiacă, agravându-le prognosticul. Impactul BRSc asupra funcției mecanice cardiace variază de la efecte minime la reducerea marcată a funcției sistolice a ventriculului stâng (VS). Activarea electrică asincronă urmată de contracția regională necoordonată a VS declanșează inițial remodelarea negativă a VS și ulterior prin creșterea persistentă a presiunii de umplere a VS, remodelarea electrică și mecanică a atriului stâng (AS). Până acum nu a fost studiată relația dintre acești parametrii EKG și remodelarea mecanică a VS. Scop - Scopul studiului este investigarea, la pacienții cu BRS, a relației dintre activarea electrică a VS și AS evaluată electrocardiografic și remodelarea mecanică a VS evaluată ecocardiografic. Metode și rezultate - Am realizat un studiu retrospectiv, observațional, nerandomizat pe un eșantion de 155 de pacienți diagnosticați BRS, consecutiv internați în clinică între ianuarie 2017 și decembrie 2019, în clasa funcțională NYHA I-IV, disfuncția sistolică a VS nu a fost criteriu de includere sau excludere. Activarea electrică ventriculară a fost evaluate prin măsurarea timpului de activare a ventriculului drept și stâng (LVAT, RVAT), iar activarea electrică a AS prin măsurarea forțelor terminale ale undei P in VI (PTFVI). DTDVS se corelează semnificativ statistic cu TAVS și FTPVI, coeficientul de corelație Pearson este mai mare pentru LVAT comparativ cu PTFVI. LVAT și PTFVI sunt predictori independenți ai remodelării mecanice a VS. Concluzii - Acest studiu demostrează că remodelarea mecanică a VS la pacienții cu BRS poate fi prezisă parțial de activarea electrică întârziată la nivelul VS și de forțele terminale negative ale undei P în VI. Cuvinte cheie: bloc complet de ramură stângă, electrocardiografie, forțe terminale ale undei $\mathrm{P}$ în VI, remodelare ventriculară.

\footnotetext{
' Department of Cardiology, „Prof. C.C. Iliescu” Institute of Emergency for Cardiovascular Diseases, Bucharest, Romania

${ }^{2}$ "Carol Davila" University of Medicine and Pharmacy, Bucharest, Romania
}

\author{
Contact address: \\ Oana Andrei, MD \\ Department of Cardiology, „Prof. C.C. Iliescu” Institute of Emergency \\ for Cardiovascular Diseases, Bucharest, Romania
}




\section{INTRODUCTION}

Left bundle branch block (LBBB) occurrence is uncommon in the general population $(\sim 1-3 \%)$, but is more prevalent among patients with congestive heart failure ( $30 \%)$, and portends worse prognosis ${ }^{1-3}$. LBBB is of major clinical importance ${ }^{4}$, being associated with a 3 to 4-fold increased risk of cardiovascular death in general population. LBBB is an electrophysiological abnormality affecting dromotropism of the conduction tissue, and electrocardiogram (ECG) is a simple and essential tool used to evaluate this type of conduction abnormality. The impact of LBBB on the left ventricular (LV) systolic function can range from minimal to dramatic reduction in left ventricular ejection fraction (LVEF). This variability is related to the left bundle branch anatomy, different levels and extent of the bundle block, different left ventricular breakthrough sites and different ranges of intrinsic myocardium contractility impairment $\mathrm{t}^{5-8}$. The negative effect of LBBB on the LV systolic function consists of delay in electrical activation which subsequently triggers dyssynchronous contraction of the LV opposing walls, leading to a loss or diminished contribution of the interventricular septum to the LV systolic function with a transfer of an excessive workload on the lateral LV wall. This is the main mechanism that triggers cardiac remodeling, promoting ventricular dilation, alteration of the heart's pumping function and elevated LV filling pressure $e^{6,7}$. The left atrium (LA) and the left ventricle are functionally and anatomically interconnected, the LA being seen as a barometer of the LV filling pressures. An elevation of the LV filling pressures will directly result in elevation of the LA filling pressures, which in turn will dilate in order to help maintain the cardiac output, according to the Frank-Starling principle ${ }^{9-12}$. Structural and functional alterations of the heart chambers are reflected on their electrophysiological properties. The ECG contains relevant information about these electric properties of the cardiac chambers. Left ventricular activation time (LVAT) has proven to be a great marker for degree of reverse remodeling in patients with resynchronization therapies ${ }^{13}$ as it was the P-wave terminal force in VI (PTFVI) ${ }^{14}$. However the relationship between these markers and mechanical remodeling as evaluated by left ventricular end-diastolic diameter (LVEDd) in patients with preserved and decreased LVEF has not been evaluated.

The aim of this study is to investigate the relationship between electric activation of left ventricular and left atrium, registered on the ECG and the mechanical remodeling evaluated by echocardiography in patients with LBBB.

\section{MATERIAL AND METHODS}

\section{Study population}

We have conducted a retrospective, observational study on I 55 consecutive patients with LBBB admitted in our clinic between January 2017 and December 2019 with NYHA class I-IV heart failure, regardless of the left ventricle ejection fraction (LVEF). The LBBB was diagnosed using conventional definition criteria $^{15,16}$ : QRSd $\geq 120 \mathrm{~ms}$, QS or $\mathrm{rS}$ complexes in $\mathrm{VI}$, wide $R$ wave - often with a notch - in DI, aVL, V5, V6, absent $Q$ wave in V5, V6). Patients with atrial fibrillation, right bundle branch block (RBBB), RV pacing, valvular heart disease worse than mild or patients with a history of acute coronary syndrome in the last 3 months were excluded.

The standard 12-lead ECG $(25 \mathrm{~mm} / \mathrm{s}, 10 \mathrm{~mm} / \mathrm{mV})$ was performed with the patient lying in supine position, during hospitalization. All ECGs were analyzed by a cardiologist blinded to echocardiographic data. All measurements were performed manually using a caliper and image zoom of at least $200 \%$.

Ventricular electric activation in LBBB was performed by measuring the right and left ventricular activation times (RVAT, LVAT). Notches that occurred in the first $40 \mathrm{~ms}$ of the $\mathrm{S}$ wave in $\mathrm{VI}$ and $\mathrm{V} 2$ leads were excluded, as they suggest ventricular scar tissue. RVAT, counting right ventricular activation time and transseptal activation time, was measured as time between QRS onset and first notch of $R$ wave in 2 or more adjacent leads (Figure I). LVAT was calculated as the difference between QRSd and RVAT ${ }^{13,17}$. The notches in QRS were identified in all the ECGs, the longest LVAT in any lead was considered for the analyses (Figure I).

Electrical activation of the LA was analyzed by measuring P-wave terminal force in VI (PTFVI), which was calculated as the product of the duration (in milliseconds) and amplitude (in $\mathrm{mV}$ ) of the negative terminal deflection of the P-wave in VI (Figure 2).

All patients were evaluated by echocardiography during hospitalization and standard parameters were recorded ${ }^{18}$. Echocardiographic images were obtained using cardiology ultrasound machines - Vivid E9 and E95 (GE Healthcare, Horten, Norway. Echocardiography images were acquired using protocols in accordance with actual recommendations. Standard echocardiographic views were obtained using harmo- 


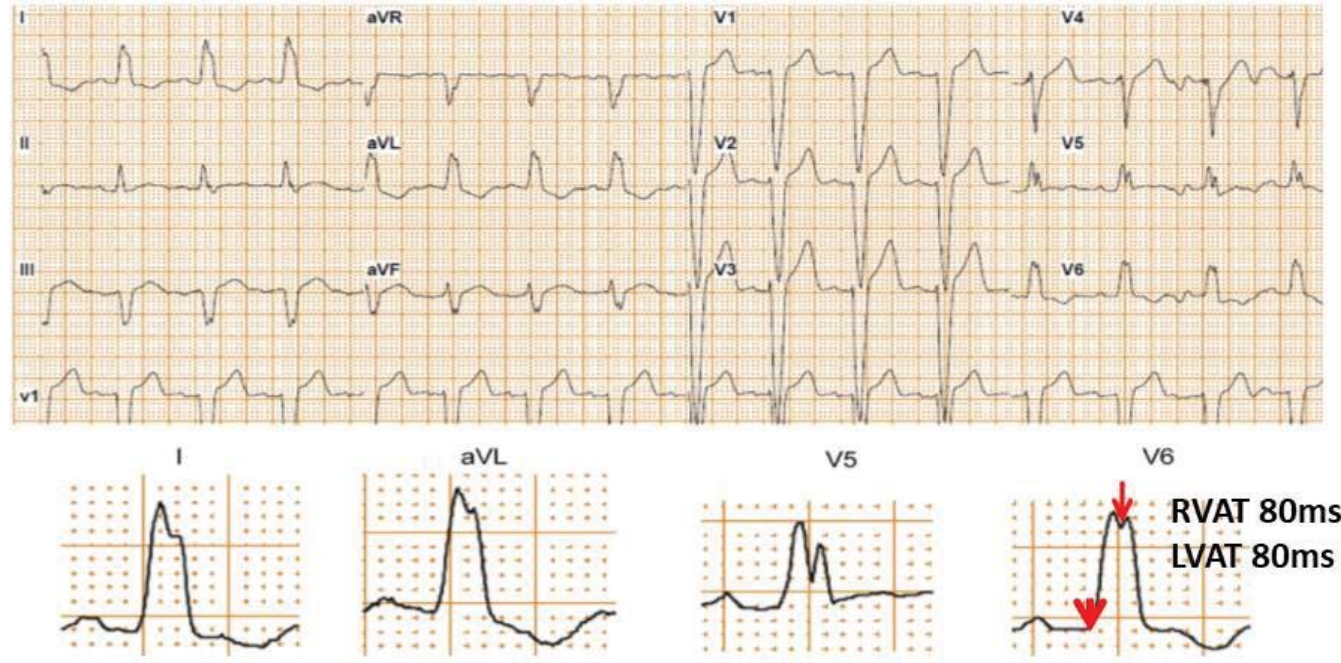

Figure I. Determination of RVAT with the use of QRS notching. Time between QRS onset (first arrow) and notch nadir (second arrow) is RVAT. LVAT is QRSd (160 msec) - $80 \mathrm{msec}=80 \mathrm{msec}$. (RVAT, right ventricular activation time; LVAT, left ventricular activation time, QRSd, duration of QRS interval).

\section{PTFV1= 70msx1,2mV=84ms*mV}

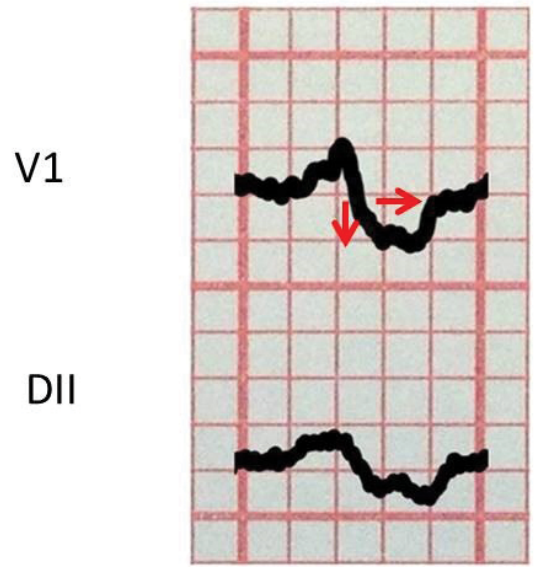

Figure 2. Measurement of PTFVI the duration of negative terminal deflection of $\mathrm{P}$ wave is multiplied by amplitude of negative terminal deflection of $P$ wave. (PTFVI, terminal forces of $P$ wave in VI).

nic imaging, adjusting the frequency of the ultrasound transducer, the depth and the width of the sector in order to optimize the frame rate $(60-80 \mathrm{fps}$ for $2 \mathrm{D}$ echography).

\section{LV size and function}

LV size, systolic and diastolic functions were evaluated in accordance with actual recommendations:

- LV end-systolic and end-diastolic diameters (LVESd, LVEDd) and the end-systolic and end-diastolic thickness of the interventricular septum and the LV posterior wall (parasternal long-axis view $-2 \mathrm{D}$ guided measurements)

- LV volumes and ejection fraction - measured on images obtain in apical 4 chamber view and apical
2 chamber view, using the modified Simpson biplane method. LV volumes were indexed to body surface area (BSA).

The primary endpoint of this study was determination of LV mechanical remodelling, as evaluated by LV end-diastolic diameter (LVEDd).

This study was conducted in accordance with Declaration of Helsinki regarding ethical principles for medical research involving human subjects.

\section{Statistical analysis}

Continuous variables were expressed as mean \pm standard deviation, while variables with skewed distribution were expressed as median or percentiles. Variables were compared using Student $t$ test. A Pearson correlation was used to evaluate the relationships of LVAT and PTFVI with LVEDd, severity of LVEF and NYHA class.

A multivariate analysis was performed with the statistically significant univariate ECG characteristics. LVEDd was the dependent variable, while the ECG parameters recorded in this study were the predictors.

To assess the comparative accuracy of different electrocardiographic variables in identifying LV remodelling, receiver operating characteristic (ROC) curves and the respective area under the curve were calculated for every parameters. Predictors of LV remodelling in patients with LBBB were assessed using binary logistic analysis. The $P$ values below 0.05 were considered statistically significant.

Statistical analysis was computed using the $R$ software, version 4.0.2 (2020-06-22), (Copyright (C) 2020 The R Foundation for Statistical Computing, R 
Core Team (2020). R: A language and environment for statistical computing. R Foundation for Statistical Computing, Vienna, Austria. URL https://www.R-project.org).

\section{RESULTS}

The study cohort included 155 patients with a mean age of $63.14 \pm 11.5$ years, $62.58 \%$ were of males, $57 \%$ in NYHA class II, $27 \%$ in NYHA class III and the mean LVEF was $39.25 \pm 14.15 \%$ (Table I). The mean QRSd was $152.69 \pm 19.08 \mathrm{~ms}$, maximum LVAT measured was in V5 and its mean was $105.68 \pm 17.38 \mathrm{~ms}$, the mean negative terminal force of $P$ wave in $\mathrm{VI}$ was $40.3 \pm 9.16$ $\mathrm{mm} * \mathrm{~ms}$ and the mean LVEDd was $59.46 \pm \mathrm{I} 1.6 \mathrm{~mm}$.

\section{Relationship of electrocardiographic parameters with left ventricular ejection fraction}

The LVAT and PTFVI was significantly different between patients with LVEF $\leq 35 \%$ and those with LVEF $>35 \%$ (LVAT II $2.12 \pm 18.689 \mathrm{~ms}$ vs $101.82 \pm 15.396$ $\mathrm{ms}, \mathrm{p}<0,001$; PTFVI $53.1818 \pm 29.94400 \mathrm{~ms}^{*} \mathrm{mV}$ vs $34.5909 \pm\left(8.38343 \mathrm{~ms}^{*} \mathrm{mV}, \mathrm{p}<0.00 \mathrm{I}\right)$. In patients with severe systolic dysfunction (LVEF $\leq 35 \%$ ) the electrical activation was more delayed and the P-wave terminal forces in $\mathrm{VI}$ were more negative.

In patients with LVEF $\leq 35 \%$, PTFVI was significantly corelated with LVEDd, but not in those with LVEF $>35 \%$ (Table 2). The relationship of PTFVI with LVEDd depending on LVEF, highlights the succession of the physio-pathological events induced by the delayed electrical activation of the LV in patients with

\begin{tabular}{|c|c|}
\hline Variable & $\begin{array}{l}\text { Study group } \\
\text { ( } n=155 \text { pts) }\end{array}$ \\
\hline Age, years \pm s.d. & $63.14 \pm 11.50$ \\
\hline $\begin{array}{l}\text { Gender M, n (\%) } \\
\text { F, n (\%) }\end{array}$ & $\begin{array}{l}97(62.58 \%) \\
58(37.42 \%) \\
\end{array}$ \\
\hline $\begin{array}{l}\text { NYHA class I, n (\%) } \\
\text { II, n (\%) } \\
\text { III, n (\%) } \\
\text { IV, n (\%) }\end{array}$ & $\begin{array}{c}8(5.16 \%) \\
72(46.45 \%) \\
55(35.48 \%) \\
19(12.25 \%)\end{array}$ \\
\hline $\begin{array}{l}\text { Coronary Present, } n(\%) \\
\text { disease Absent, } n(\%)\end{array}$ & $\begin{array}{c}23(14.84 \%) \\
132(85.16 \%)\end{array}$ \\
\hline $\begin{array}{l}\text { QRSd below } 150 \mathrm{~ms}, \mathrm{n}(\%) \\
\text { above } 150 \mathrm{~ms}, \mathrm{n}(\%)\end{array}$ & $\begin{array}{c}52(33.54 \%) \\
103(66.46 \%)\end{array}$ \\
\hline $\begin{array}{l}\text { LVEF (\%) below 35\%, n (\%) } \\
\text { above 35\%, n (\%) }\end{array}$ & $\begin{array}{l}78(50.32 \%) \\
77(49.68 \%)\end{array}$ \\
\hline $\begin{array}{l}\text { LVEF } \leq 35 \% \text { dilated CMP n (\%) } \\
\text { ischemic CMP n (\%) }\end{array}$ & $\begin{array}{l}63(83.11 \%) \\
15(16.89 \%)\end{array}$ \\
\hline Mean LVEDd \pm s.d. & $59.84 \pm 11.73 \mathrm{~mm}$ \\
\hline
\end{tabular}

LBBB, as LV remodeling and systolic dysfunction precede electrical and haemodynamic alterations in the LA.

\section{Association between electrocardiographic parameters and left ventricular mechanical remodeling in left bundle branch block patients}

In order to analyze the relationship between LV mechanical remodeling and electrical dyssynchrony we used univariate and then multivariate linear regression, the dependent variable being the LVEDd (Table 3). The predictors were ECG parameters known to be associated with LV electrical dyssynchrony.

Multivariate linear regression only included significant parameters identified in the univariate linear regression, using the backward selection algorithm (the regression model found in the (Table 4); the multiple regression model included only ECG parameters.

The multiple regression model identified only 2 independent parameters out of 10 (LVAT and PTFVI), showing significant collinearity of the predictors identified in the simple regression (Table 4). The R2 (Rsquare) in the model was 0.352 , the two ECG parameters explaining slightly more than I/3 of the LVEDd

\begin{tabular}{|c|c|c|}
\hline & LVEF $\leq \mathbf{3 5} \%$ & LVEF $>35 \%$ \\
\hline Predictors & $\begin{array}{l}\text { LVEDd } \\
r \text { Pearson ( } p \text { Value) }\end{array}$ & $\begin{array}{l}\text { LVEDd } \\
r \text { Pearson ( } \mathrm{p} \text { Value) }\end{array}$ \\
\hline PTFVI & $0.46(0.0004)$ & $-0.16(0.1209)$ \\
\hline LVAT & $0.49(0.0001)$ & $0.33(0.0012)$ \\
\hline
\end{tabular}

\begin{tabular}{|c|c|c|c|}
\hline Predictor & T-statistic & p-value & Coefficient [IC $95 \%]$ \\
\hline PR interval & -0.476 & 0.6340 & $-0.007[-0.03$ to 0.02$]$ \\
\hline $\mathrm{Pa}-\_\mathrm{VI}$ & 2.451 & 0.0154 & $5.68[1.10$ to 10.26$]$ \\
\hline Pd__VI & 2.114 & 0.0361 & $0.06[0.01$ to 0.13$]$ \\
\hline Pdt_VI & 2.083 & 0.0389 & $0.10[0.005$ to 0.20$]$ \\
\hline PTFVI & 4.276 & $<0.0001$ & $0.13[0.07$ to 0.19$]$ \\
\hline QRS axis & -2.367 & 0.0192 & $-0.06[-0.12$ to -0.01$]$ \\
\hline QTc & 2.295 & 0.0230 & $0.04[0.006$ to 0.08$]$ \\
\hline QRSd & 5.040 & $<0.0001$ & $0.23[0.14$ to 0.32$]$ \\
\hline LVAT & 6.489 & $<0.0001$ & $0.32[0.22$ to 0.42$]$ \\
\hline T_d & 1.810 & 0.0722 & $0.06[-0.005$ to 0.12$]$ \\
\hline RVAT & 0.79 & 0.431 & $0.9[-0.066$ to 0.12$]$ \\
\hline PT_FT/QTc & 0.814 & 0.4170 & $21.19[-30.42$ to 73.01$]$ \\
\hline \multicolumn{4}{|c|}{$\begin{array}{l}\text { Pa--VI, amplitude of negative } \mathrm{P} \text { wave in VI lead; Pd-_VI, duration of negative Pwave in VI leac } \\
\text { PTFVI, negative terminal force of } \mathrm{P} \text { wave in VI; QRSd, QRS duration; LVAT_V, left ventricular } \\
\text { activation time in V5 lead; QTd, QT interval duration; T_d, duration of T wave, PT_FT/QTc, } \\
\text { the ratio between the time from the peak of the T wave to the end of the T wave and QTc } \\
\text { interval duration; RVAT, right ventricular activation time. }\end{array}$} \\
\hline
\end{tabular}




\begin{tabular}{|l|l|l|l|}
\hline Table 4. ECG parameters predictors of LV mechanical remodeling & Coefficient [IC95\%] \\
\hline Predictor & T-statistic & p-value & $0.09[0.04$ to 0.15$]$ \\
\hline PTFVI & 3.570 & 0.0004 & $0.28[0.19$ to 0.37$]$ \\
\hline LVAT & 6.169 & $<0.000 \mathrm{I}$ & \\
\hline LVAT, left ventricular activation time; PTFVI, terminal forces of P wave in VI; &
\end{tabular}

\begin{tabular}{|c|c|c|c|c|c|}
\hline \multicolumn{6}{|c|}{ Table 5. R-squared - the strength of the relationship between PTFV I, LVAT and LVEDd } \\
\cline { 4 - 6 } Model & $\mathbf{R}$ & R Square & R Square Change & Change Statistics \\
\cline { 3 - 6 } & $.577^{\mathrm{a}}$ & .352 & .352 & 41.590 & Shange \\
\hline I & \multicolumn{3}{|l}{} \\
\hline
\end{tabular}

variation (Table 5). The important collinearity of the predictors is demonstrated by the statistically significant correlations between them.

The analysis of the correlation between LVEDd, LVAT and PTFVI showed a higher Pearson correlation coefficient for LVAT compared to PTFVI (Figure 3).

Binary logistic regression, with dependent variable LVEDd greater than $55 \mathrm{~mm}$ for male and $53 \mathrm{~mm}$ for female (yes/no) and predictors categories of LVAT and PTFVI (determined with a ROC analysis), show that LV significant dilatation is predicted by LVAT higher than $105 \mathrm{~ms}$ with $50 \%$ specificity and $75 \%$ sensitivity and by PTFVI greater than $65 \mathrm{~ms}^{*} \mathrm{mV}$ with $86 \%$ specificity and $25 \%$ sensitivity. Therefore, mechanical LV remodelling is accurately identified by PFTVI higher than $65 \mathrm{~ms}^{*} \mathrm{mV}$ (Table 6, Figure 4).

\section{DISCUSSIONS}

This study indicates that LV mechanical remodeling, as evaluated by LVEDd, in patients with LBBB can be predicted by the delayed electrical activation of the LV and the $\mathrm{P}$-wave negative terminal forces in $\mathrm{VI}$, which reflects high LV filling pressures, with a significant correlation with LVEDd.

Left bundle branch block is a complex electrical disease that causes a block in the conduction of the electrical impulse at different anatomical levels and leads to its abnormal propagation in the LV myocardium. In 2004 Aurichio et al. described the LV electrical activation pattern during LBBB using 3D contact and non-contact mapping, ${ }^{6,19}$. They showed that electric impulse propagation in the left ventricular myocardium originates in RV, followed by a transseptal propagation to the LV septal endocardium, from mid to apex. In a heart with normal conduction system, transseptal conduction requires about $20 \mathrm{~ms}$, but in patients with LBBB it requires more than $40 \mathrm{~ms}$, indicating slow, myocardial to myocardial cell conduction. Afterwards, the wave front continue to spread from mid or apical septal LV endocardium to the posterolateral LV wall through the apex and inferior wall. This
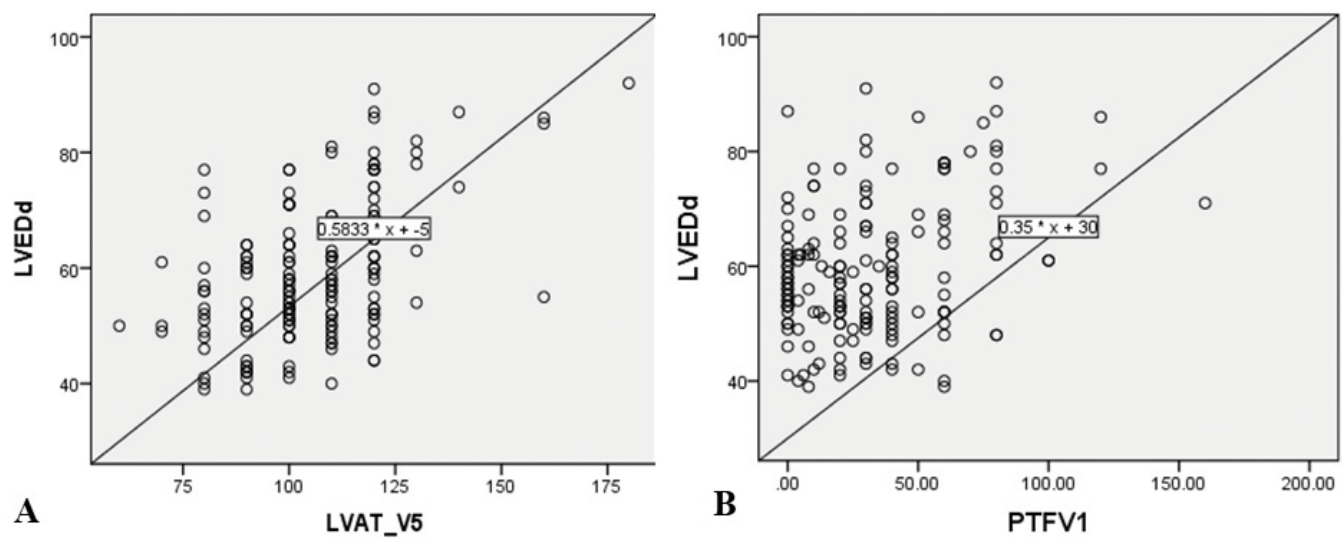

Figure 3. LVEDd plotted as a function of LVAT (A) and PTFVI (B). This figure demonstrate the higher correlation for LVAT compared to PTFVI. LVAT, left ventricular activation time; LVEDd, left ventricular end diastolic diameter; PTFVI, terminal forces of $\mathrm{P}$ wave in VI. 


\begin{tabular}{|l|l|l|l|}
\hline Table 6. PTFVI $>$ 65ms*mV and LVAT > I 05ms predict accurately LV dilatation \\
\hline Predictor & Coefficient & P Value & OR [IC95\%] \\
\hline PTFVI >65 & & 0.0158 & $6.42[1.73$ to 4I.69] \\
\hline LVAT >I05 & I.I5 & 0.0009 & $3.17[1.61$ to 6.40] \\
\hline LVAT, left ventricular activation tim; PTFVI, terminal forces of P wave in VI.
\end{tabular}

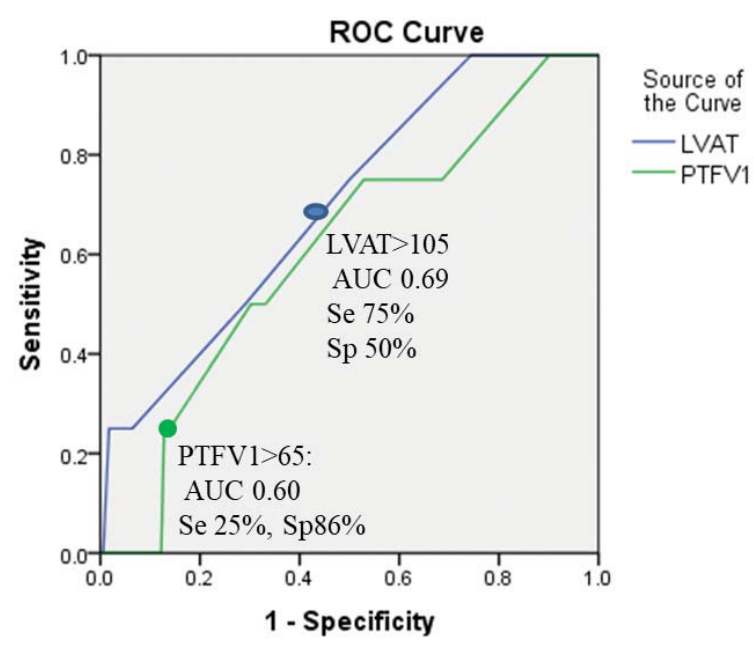

Figure 4. ROC curves for LVEd vs LVAT and PTFVI. LVAT, left ventricular activation time; LVEDd, left ventricular end diastolic diameter; PTFVI, terminal forces of $\mathrm{P}$ wave in $\mathrm{VI}$.

"U-shaped" electro-mechanical activation pattern is caused by lines of functional conduction block (Figure 5) described during electrophysiology studies. Lines of functional block are located in the anterior, lateral and inferior LV wall. The transseptal delay and the sites of LV breakthrough are the major determinants of the location of the lines of functional block and the QRS duration, in LBBB. Therefore, patients with apical LV septal breakthrough site have a line of functional block located in the anterior wall, and are related to more severe interventricular and intraventricular electrical dyssynchrony compared to patients with other LV breakthrough sites. The anterior location of block line will cause electro-mechanic activation of the septum to propagate along the apex and the inferior wall, toward the lateral or posterior wall, without directly passing through the anterior wall, as would happen in the healthy heart. Therefore, the last segment to activate is the basal region of the lateral or posterolateral

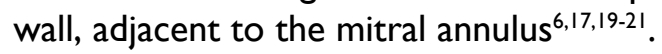

Electrical depolarization initiates myocardial mechanical contraction. This sequential electro-mechanic activation of the myocardium causes the dyssynchronous contractions of opposing walls of the LV. As a

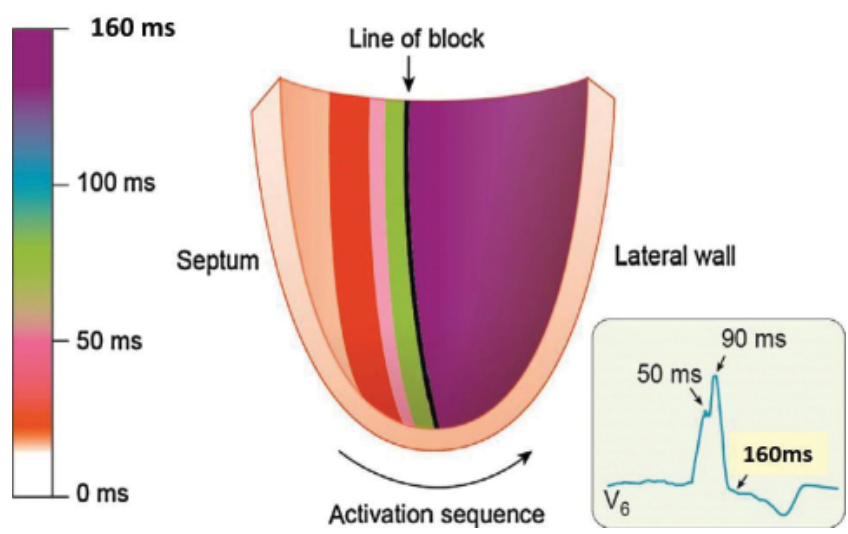

Figure 5. "U" shaped pattern of electrical activation caused by wavefront propagation around the apex due to line of functional block, explaining the presence of notching on the ECG (adapted from Kanawati et al. ${ }^{20}$ ).

consequence of in-coordinated contractions, the shortening of the first electrical activated walls will induce stretching of the opposing myocardial walls, which are electrical activated later ${ }^{22}$. The mechanical stretching of the myocardium further delays the propagation of the electric impulse, as a result of the molecular alterations in the connexin 43 and the calcium channels $s^{6,21}$. In LBBB, the septum is the first segment of the LV myocardium to contract, and its contraction begins before the opening of the aortic valve, occurring during isovolumetric contraction period, against low pressures before opening of the aortic valve. Hence, it doesn't contribute to the cardiac output. This way the septal workload is wasted, causing lateral wall stretching and increasing its workload. According to the Frank-Starling law, the pre-stretched lateral wall has a vigorous contraction that determines increasing intraventricular pressure, causing opening of the aortic valve and ejection of blood, along with stretching and left-to-right movement of the septum. Since the septum is a third of the LV mass, the important septal workload waste causes lateral wall overload, triggering the harmful LV mechanical remodeling, which consists of asymmetrical hypertrophy of the lateral wall and LV dilation, along with an increase in the LV filling pressures $^{2,6,7,22-24}$. Hemodynamic alterations in the LV directly and rapidly affect the electromechanical function of the LA, which is considered a "barometer" of dias- 
tolic burden of the LV9-12. Therefore, LA anatomical and functional changes mirror the cumulative effects of LV filling pressures over time, comparable to the role of hemoglobin AIc in diabetes ${ }^{11,12}$. Consequently, LA electro-anatomic remodeling provides more sensitive and probably more accurate markers of diastolic dysfunction severity than the usual LV diastolic function parameters, that are highly variable and related to hemodynamic status at the time of examination ${ }^{23-27}$. In a recent review, regarding $L A$ importance in patients with LBBB and LV systolic disfunction which were candidates for CRT, Camelli et al showed that LA structural and functional parameters are independent predictors of outcome, in these patients?.

The relationship between LBBB and LV remodeling is supported by numerous experimental and clinical studies. In 2018, Auffret et al. reviewed data and concluded that LBBB promotes structural remodeling and LV systolic dysfunction ${ }^{28}$.

The ECG records the abnormal electrical activation and its consequences. The ECG image of the activation wavefront reaching the endocardium of the LV septum is the first $R$ wave notch, while the second $R$ wave notch represents the beginning of depolarization of the epicardium of the LV lateral wall. QRS morphology is insignificantly changed between these two notches due to the fact that the direction and magnitude of the mean electrical vector is constant, as the depolarization occurs in the LV myocardial wall ${ }^{29}$. Total electrical activation time in LBBB patients is 80 150 ms longer than in normal conduction ${ }^{29}$. The duration and morphology of QRS complexes represent a crude image of the asynchronous intramyocardial electrical activation, that is based both on the electrical asynchrony caused by abnormal conduction tissue and the mechanical asynchrony caused by intrinsic myocardial alterations (such as overload, hypertrophy, fibrosis, scar tissue $)^{22,30}$. In order to aid identification of patients with QRS morphology predominantly resulting from altered conduction tissue, Strauss et al introduced a novel electrocardiographic definition of complete LBBB, emphasizing that criteria for LBBB should include the presence of the two $R$ wave notches in at least two contiguous lateral leads ${ }^{29}$. Sweneey et al analyzed the relationship between the electrical activation of the LV as recorded on the ECG and the structural changes of the LV, and showed that LVAT is an independent predictor of mechanical remodeling of the LV and of CRT response ${ }^{13}$. Our study showed the statistically significant correlation between mecha- nical LV remodeling assessed by LVEDd and LVAT in patients with LBBB.

ECG signs of LA overload are determined by a leftward and posterior shift of the electrical vectors of $\mathrm{P}$ wave in the horizontal plane, causing a predominantly negative component of the $\mathrm{P}$ wave in $\mathrm{VI}^{27}$. In a study assessing the structure and function of the LV and LA by cardiac MRI, Tiffany et al revealed the underlying mechanisms of the electrocardiographic indices of the $P$ wave. They indicated that electrical alterations caused by LA overload, assessed by PTFVI, are independent predictors of fibrosis in the LV before structural and functional changes of the $\mathrm{LA}^{27}$. Baturova et al showed, in a sub-study of the MADIT-CRT trial, that the electrical LA abnormality expressed as PTFVI on ECG was a sign of electrophysiological LA changes caused by LV remodeling. PTFVI had an additive prognostic insight for LBBB patients. Normal PTFVI is an independent predictor of better prognosis regardless of $L A$ volume ${ }^{23}$. The $P$ wave morphology is in part influenced by LA volume, but it is unlikely to be the sole determinant ${ }^{24}$. Left atrial remodeling includes structural, ultrastructural, ionic and electrical remodeling. The electrical remodeling is considered to be induced by alterations of expression and function of ion channels and gap junctions in the cardiac myocyte ${ }^{25}$.

The relationship between LV remodeling and mechanical dyssynchrony was analyzed by Tayal et al., who showed that significant negative remodeling of the $L V$, quantified as LVEDV is a negative predictor of CRT response. They highlight the fact that severe dilation of $L V$ involves both electromechanical asynchrony and severe remodeling, which further increase the fibrotic burden of the LV myocardium ${ }^{31}$. Bernard-Brunet et al demonstrated high predictive value of a score for CRT response, in which LV mechanical remodeling was assessed by LVEDd ${ }^{32}$. In a review, Vernooy et al analyzing the factors related to favorable response to cardiac resynchronization therapy, found that increased LVEDV was an independent predictor of the absence of $L V$ reverse remodeling after $C R T^{32}$. The results of several studies emphasized the prognostic significance of LVED diameter and volume. Severe LV dilation predicted lack of response to $C R T^{34}$. Instead, moderate remodeling predicted a favourable response to $\mathrm{CRT}^{29}$. In patients with LBBB and moderate LV systolic dysfunction, LVEDv predicted progression to severe LV dysfunction ${ }^{35}$.

The results of our study highlighted the interrelationship between electrical LV asynchrony and elec- 
trical LA changes and mechanical LV remodeling in patients with LBBB. LV dilation is partially predicted by the duration of LV electrical activation and by the abnormal electrical forces of the left atrium. LVEDd better correlated with LVAT than with PTFVI, even though both correlations were statistically significant.

\section{CLINICAL IMPLICATIONS}

ECG decoding of patients with CLBBB should include not only a rigorous analysis of the QRS complex, but also a careful characterization of the atrial depolarization, by assessing the $\mathrm{P}$ wave morphology. Thorough understanding of cardiac electrical activity, well-integrated in clinical context, may improve optimal treatment strategy for each patient.

\section{LIMITATIONS}

This represented the experience of a single center. A first limitation of this study was the retrospective nature of it, as electrocardiographic and echocardiographic evaluations were performed in conventional settings. For this reason, the chosen parameter for evaluating mechanical remodeling was LVEDd and not LVEDv. Data demonstrating the significance of this parameter support our choice. Another limitation of our study was that all ECG measurements were carried out manually, enlarging the image by at least $200 \%$.

\section{CONCLUSION}

In patients with LBBB on ECG, LVAT and PTFVI were significant correlated with left ventricular remodeling as demonstrated by LVEDd.

The heart's electric signature can be a subtle indicator of cardiac function and anatomy, providing valuable prognostic and therapeutic clues.

\section{Conflict of interests: none declared.}

\section{References}

I. Kevin Vernooy, Xander A.A.M. Verbeek, Maaike Peschar et al. Left bundle branch block induces ventricular remodelling and functional septal hypoperfusion. Eur. Heart. J.2005;26:91-98.

2. Otto A. Smiseth, John M. Aalen. Mechanism of harm from left bundle branch block. Trends in Cardiovascular Medicine 2018; I I: 38.

3. Faiez Zannad, Etienne Huvelle, Kenneth Dickstei et al. Left bundle branch block as a risk factor for progression to heart failure. Eur. J. Heart Failure 2007;9:7-I4.

4. Kurtuluș Özdcmir, Bülent B. Altunkeser, Gülizar Damș et al. Effect of the isolated left bundle branch block on systolic and diastolic functions of Left Ventricle. J. of Am. Soc. Echocardiogr 200I;|4:10751079.

5. Guang-yuan Li, Yong-huai Wang, Zheng-yu Guan et al. Effect of septal flash on right ventricular systolic function in left bundle-branch block patients with preserved left ventricular ejection fraction. www.nature.com/scientificreports/ 2017.
6. John M. Aalen, Espen W. Remme, Camilla K. Larsen et al. Mechanism of Abnormal Septal Motion in Left Bundle Branch Block. Role of Left Ventricular Wall Interactions and Myocardial Scar. J. Am Coll. Cardiol Img 2019;12:2402-24I3.

7. Simon Calle, Christophe Delens, Victor Kamoen et al. Septal flash: At the heart of cardiac dyssynchrony. Trends in Cardiovascular Medicine 2020;30: I 15-122.

8. Gaurav A. Upadhyay, Tharian Cherian, Dalise Y. Shatz et al. Intracardiac Delineation of Septal Conduction in Left Bundle-Branch Block Patterns Mechanistic Evidence of Left Intrahisian Block Circumvented by His Bundle Pacing. Circulation 2019;139:1876-1888.

9. Matteo Cameli, Maria Concetta Pastore, Michael Y. Henein et al. The left atrium and the right ventricle: two supporting chambers to the failing left ventricle. Heart Fail Rev 2019;24:66I-669.

10. Antonello D'Andrea, Pio Caso, Silvio Romano et al. Different effects of cardiac resynchronization therapy on left atrial function in patients with either idiopathic or ischaemic dilated cardiomyopathy: a twodimensional speckle strain study. Eur Heart.J.2007;28:2738-2748.

II. Damien Feneon, Albin Behaghel,MD, Anne Bernard et al. Left atrialfunction, a new predictor of responsetocardiac resynchronizationtherapy? Heart Rhythm 2015;12:1800-1806.

12. Rafael Kuperstein, Ilan Goldenberg, Arthur J. Moss et al. Left Atrial Volume and the Benefit of Cardiac Resynchronization Therapy in the MADIT-CRT Trial. Circ heart Fail.2014;7:I54-160.

13. Michael O. Sweeney, Rutger J. van Bommel, Martin J. Schalij et al. Analysis of Ventricular Activation Using Surface Electrocardiography to Predict Left Ventricular Reverse Volumetric Remodeling During Cardiac Resynchronization Therapy. Circulation 2010;121:626-634.

14. Maria A. Baturova, Valentina Kutyifa, Scott McNitt et al. Usefulness of Electrocardiographic Left Atrial Abnormality to Predict Response to Cardiac Resynchronization Therapy in Patients with Mild Heart Failure and Left Bundle Branch Block (a MADIT-CRT Sub-Study). Am J Cardiol 2018;122:268-274.

15. Kelley P. Anderson. Left bundle branch block and the evolving role of QRS morphology in selection of patients for cardiac resynchronization. J Interv Card Electrophysiol 2018;52:353-374.

16. Elena Surkova, Luigi P. Badanol, Roberto Bellu et al. Left bundle branch block: from cardiac mechanics to clinical and diagnostic challenges. Europace 2017;19:1251-1271.

17. Elien B. Engels, Masih Mafi-Rad, Antonius M.W. van Stipdonk et al. Why QRS Duration Should Be Replaced by Better Measures of Electrical Activation to Improve Patient Selection for Cardiac Resynchronization Therapy. J of Cardiovasc Trans Res 2016;9:257-265

18. Roberto M. Lang, Luigi P. Badano, VictorMor-Avi et al. Recommendations for Cardiac Chamber Quantification by Echocardiography in Adults: An Update from the American Society of Echocardiography and the European Association of Cardiovascular Imaging. Eur Heart J Cardiovasc Img 2015; 16: 233-27I

19. Angelo Auricchio, MD, Cecilia Fantoni, Francois Regoli et al. Characterization of Left Ventricular Activation in Patients With Heart Failure and Left Bundle- Branch Block. Circulation 2004; 109: I I 33-I I 39.

20. Juliana Kanawati, RaymondW.Sy. Contemporary Review of Left Bundle Branch Block in the Failing Heart-Pathogenesis, Prognosis, andTherapy. Herat Lung circ 2018;27:291-300.

21. Yoshihiro Seo, Tomoko Ishizu, Fumiko Sakamaki et al. Left bundle branch block and echocardiography in the era of CRT. J Echocardiogr 2015;13:6-14.

22. Niels Risum, David Strauss, Peter Sogaard et al. Left bundle-branch block: The relationship between electrocardiogram electrical activation and echocardiography mechanical contraction. Am Heart J 2013;166:340-8.

23. Jonathan A. Kirk, David A. Kass. Electromechanical Dyssynchrony and Resynchronization of the Failing Heart. Circ Res. 2013; I 13:1-27.

24. Fredrik Holmqvist, Pyotr G. Platonov, Scott D. Solomon et al. Pwave Morphology Is Associated with Echocardiographic Response to Cardiac Resynchronization Therapy in MADIT-CRT Patients. Ann Noninvasive Electrocardiol 2013;18:510-518.

25. Bryce Alexander, Fariha Sadiq, Kousha Azimi et al. Reverse atrial electrical remodeling induced by cardiac resynchronization therapy. 
J electrocardiology 2017;50:610-614.

26. Nicolas Johner, Mehdi Namdar, Dipen C. Shah. Intra- and interatrial conduction abnormalities: hemodynamic and arrhythmic significance. J. interv Card electrophysiol 2018;52:293-302.

27. Theingi Tiffany Win, Bharath Ambale Venkatesh, Gustavo J Volpe et al. Associations of Electrocardiographic P-wave Characteristics with Left Atrial Structure, Function and Diffuse Left Ventricular Fibrosis Defined by Cardiac Magnetic Resonance: the PRIMERI Study. Heart Rhythm 2015; I2:155-162

28. Vincent Auffret, Raphaël P. Martins, Claude Daubert et al. Idiopathic/ latrogenic Left Bundle Branch Block-Induced Reversible Left Ventricle Dysfunction JACC State-of-the-Art Review. J Am Coll Cardiol 2018;72:3177-3188.

29. David G. Strauss, Ronald H. Selvester, Galen S. Wagner. Defining Left Bundle Branch Block in the Era of Cardiac Resynchronization Therapy.Am J Cardiol 201 I; 107:927-934.

30. Jeanne E. Poole, Jagmeet P. Singh, Ulrika Birgersdotter-Green. QRS Duration or QRS Morphology. What Really Matters in Cardiac Resynchronization Therapy? J Am Coll Cardiol 2016;67:1 I04-III 7.

31. Bhupendar Tayal, Peter Sogaard, Antonia Delgado-Montero et al. In- teraction of Left Ventricular Remodeling and Regional Dyssynchrony on Long-Term Prognosis after Cardiac Resynchronization Therapy. J Am Soc Echocardiogr 2017;30:244-250.

32. Anne Brunet-Bernard, Sylvestre Maréchaux, Laurent Fauchier et al. Combined Score Using Clinical, Electrocardiographic, and Echocardiographic Parameters to Predict Left Ventricular Remodeling in Patients Having Had Cardiac Resynchronization Therapy Six Months Earlier. Am J Cardiol 2014; I 3:2045-20I5I.

33. Kevin Vernooy, Caroline J. M. van Deursen, Marc Strik and Frits W. Prinzen. Strategies to improve cardiac resynchronization therapy. Nat Rev Cardiol 2014;1 I:48I-93.

34. Ziqing Yu, Xueying Chen, Fei Han et al. Electro-echocardiographic Indices to Predict Cardiac Resynchronization Therapy Non-response on Non-ischemic Cardiomyopathy. www.nature.com/scientificreports/ 2017.

35. Piero Gentile, Alessia Paldino, Antonio Cannatà et al. Left bundle branch block in dilated cardiomyopathy with intermediate left ventricular dysfunction: Clinical phenotyping and outcome correlates. Int J Cardiol 2019;278: 180-185. 